\title{
MOTIVES FOR FIRST SEXUAL INTERCOURSE IN THE CONTEXT OF RISK AND ETHICAL ASPECTS OF SEXUAL CAREER
}

\author{
Dagmar Marková
}

\begin{abstract}
The text is focused on the issue of ethical and risk context of the motives of the first sexual intercourse in heterosexual relationships. We present the results of a broader study that dealt with attitude and behavioral attributes of majority and minority sexual life styles of men and women of younger, middle and older adult age in Bohemia and Slovakia and with their sociocultural and ethical contexts. The results suggest that the first sexual intercourse is most frequently related to love and partnership. A frequent incidence of sexual debut motives containing different degrees of elements of highrisk sexual behaviour was identified. That may suggest some aspects of sexual morals and at the same time serve as a useful tool of sexual education in connection with the development of sexual health.
\end{abstract}

\section{Keywords}

Sexuality, sexual morals, first sexual intercourse, coital sexual activities, sexual research, sexual health, high-risk sexual behaviour.

\section{Introduction ${ }^{1}$}

The research of the first sexual experience provides important ethical information about the normative systems shaping social interactions and individual experience. The first sexual experiences, as compared to all other sexual activities, are even more related to a comprehensive series of cultural and moral regulations and expectations. As Supeková

\footnotetext{
1 The text was created thanks to the support of the VEGA 2/0027/17 grant: Traditional and alternative parenthood of the $21^{\text {th }}$ century: motivation, dilemmas and consequences.
} 
and Bianchi (2000) state, to understand an individual's sexual behaviour, it is important to know the behaviour motivation, as well as the individual patterns (scenarios) of sexual behaviour or the context of such behaviour.

The beginnings of partner-oriented sexuality are diverse. As Dannenbeck and Stich (2005) mention, the beginning of the process of partner experiences and learning cannot be exactly defined, similarly to the beginning of the process of sexual learning. There are many beginnings: first falling in love, first friendship defined as couple relationship by the youth, first caresses, intensive kissing, first experiences with petting, first sexual intercourse, etc. The first sexual intercourse is usually considered an important key event in the individual's sexual career. Bernik and Hlebec (2003) point out that at individual level, the first sexual intercourse is considered a critical stage of the individual life story and personality development. Stich (2003), on the other hand, states that the first sexual intercourse is only an event in the sexual learning process. Boys and girls experience their first intercourse as an important step, but it is not a loss of something that has a preservation value but a celebration of an important transition to the best possible beginning.

As for the investigation of motives, circumstances and factors of sexual debut, the research (Nöstlinger \& Wimmer-Puchinger, 1994) suggests that boys and girls fell in love for the first time, had their first date and got their first kiss at the age of thirteen. They had the first permanent partner about the age of fourteen and the first petting at the age of fifteen. They had the first homosexual petting at the age of thirteen and half and the first sexual intercourse usually at the age of sixteen. It has been also shown (BZgA, 2006) that the first petting experience are very important for the ability of sexual behaviour, as boys and girls learn to recognize the other person's signals and to communicate in sex through them. Dannenbeck, Stich (2005) state that those who did not have petting experience before their first sexual intercourse tried to justify it (e.g. by missing opportunities) during the interviews. It is difficult to distinguish whether the missing sexual experience was the cause of problems at the first sexual intercourse or whether it was caused by a former problematic attitude to sexuality. Both causes usually contribute to an unfavourable beginning of partner-oriented sexuality. The natural petting practice leads the youth to bilaterally suppose some sexual experience. If such experience is missing, sexual understanding is burdened by irritations, as own former experience cannot be implemented as familiar. Absolutely inexperienced girls are twice as much uncertain during the first sexual relationships: they have troubles to correctly distinguish situations and signals and they are afraid to confess their low sexual experience, which restricts sexual curiosity and relaxed feeling of sex.

With respect to the differences between boys and girls, the results of an extensive American study (Laumann, Gagnon, Michael, \& Michaels, 1994) summarize that men start sooner, have more sexual partners and they are motivated by curiosity and interest in sex. Women start later, have sex primarily with their husbands or in permanent relationships and are more interested in protection. Martin (2002) states, based on 
her research findings, that boys and girls get to sex through different paths - girls are usually forced to sex and boys are those who force them. The first and initial sexual experiences have different psychological consequences for boys and girls. Sexual experiences of boys often lead them to feel older, more masculine and more connected with other men. Such positive consequences are much more difficult to achieve in case of girls. Their first and initial sexual experiences usually lead to confused feelings of uncertainty about themselves and about their bodies. European studies refer about general reduction of differences between men and women in connection with the first sexual intercourse (e.g. Bozon \& Kontula, 1998; Narring, Wydler, \& Michaud, 2000, etc.). Also Schmidt's studies (2003) suggest that romanticization of male sexuality goes hand in hand with self-determination of female sexuality - in 1970, $80 \%$ adolescent girls reported to have had the first sexual intercourse "to make the boy happy"; today, less than $20 \%$ girls state it.

Studies of motivation of the first sexual intercourse made in Slovakia and in Bohemia suggest disappearing of inter-gender differences in the issue of the age of start of sexual life, as well as some taking over of boy's motives to first sexual intercourse by girls. Lukšík (1997) found out that most frequently the following motives for the first sexual intercourse are reported: desire to have it (b: $64.5 \%, \mathrm{~g}: 52.5 \%$ ), love to the partner (b: $44.4 \%$, g: $65.5 \%$ ), curiosity (b: $22 \%$, g: $25.7 \%$ ), the partner wanted it (b: $34.4 \%$, g: $17.9 \%$ ). Koliba (1996) warns in connection with the importance of love at the first sexual intercourse that $30 \%$ boys and $22 \%$ girls think that love is not so important. Our study (Szabó \& Švihelová, 2001) shows that the age of the first sexual experience and the motives of the first sexual intercourse are mutually related. Those who had their first sexual intercourse before the age of seventeen reported love to the partner as a motive by $16 \%$ less than those who had it after the age of seventeen years; curiosity was reported as a motive by $29 \%$ of those who had their first sexual intercourse before the age of seventeen, while the second group reported it only in $4 \%$, etc.

Bianchi (2001) states that in relation to the risk level of sexual behaviour, the average age is most frequently researched and important correlates of risk level of sexual career with early sexual debut (before the age of sixteen) are often found, for example in the number of sexual partners in life, in the number of accidental sexual partners, in consumption of habit-forming psychoactive substances, etc. The research of motives of the first sexual intercourse, made at a population sample with high-risk behaviour (Bianchi, 2001) shows major differences in the incidence of individual motives in different countries. In Slovakia, the motives include primarily: high incidence of emotional blackmail (in women), "desire" / hormones (in men), opportunity - willing female partners (in men), opportunity - favourable circumstances (in men), peer pressure (in men) and feeling of social obligation (in men). In the Netherlands, the motives include primarily: low incidence of feeling of social obligation, peer pressure, "desire" / hormones, opportunity adequate partner, physical attraction and opportunity - favourable circumstances and frequently reported natural development / progress of the relationship as a motive for the first sexual intercourse. Finally, in England, the motives rarely include natural progress 
of the respondent's sexual development and they frequently include spontaneity / "it just happened" (in women), feeling of a correct thing, physical attraction and influence of alcohol / drug consumed.

The above stated facts show that the sexual debut is not only an important event in the individual's sexual career but that the first sexual experiences are embedded in specific normative and cultural frameworks. The high-risk aspects of the first sexual intercourse are connected not only with a lower age of the first sex but also with its motivation and other circumstances containing both first-level and second-level aspects of sexual health which, according to Lukšík and Supeková (2003), constitute personal, personality, social and cultural dimensions of sexuality. Therefore this text analyzes the motives of the first sexual intercourse in the contexts of risk level from the perspective of sexual health and of its moral aspects.

\section{Research}

This text presents partial results of a broader research concerning majority and minority heterosexual partner and sexual life styles and preferences in the area of sexual moral of men and women of younger, middle and older adult age in Slovakia and in Bohemia. We focus only on the analysis of the data concerning motivation for the first sexual intercourse in heterosexual relationships and we describe the differences in the motives of the sexual debut related to age, gender, Czech and Slovak nationality, as well as religious and moral preferences (narrowed to three types: absolutism, relativism and hedonism).

\section{Research methods}

Our research made use of several quantitative and qualitative methods. The research tools included also a questionnaire constructed by us, which included a part focused on sexual career. That part of the questionnaire was divided into two sections: sexual and partner experiences in the period before and after the first sexual intercourse were investigated separately. The results presented in this text were acquired through the questionnaire and they concern the motives of the sexual debut.

\section{Research set}

The research set consisted of 1,022 persons of younger, middle and older adult age from Slovakia and the Czech Republic. It was put together by full-time and external students of Constantine the Philosopher University in Nitra, Komenský University in Bratislava, Matej Bel University in Banská Bystrica, Prešov University in Prešov, University of Hradec Králové, Silesian University in Otava and their separate units. It must be mentioned that 
the research set is not a representative selection, that women, younger adult persons and Slovak respondents prevailed in it and that university students participated in the research.

\section{Research findings}

\section{Motivation for first sexual intercourse}

The study of the beginning of partner-oriented sexuality also ascertained the motives of the first coitus. According to our data, the beginnings of couple sexuality are most frequently motivated by love (table and diagram No. 1) - $23 \%$ of the respondents reported love to the partner as the motive for the first sexual intercourse. The data analysis shows that the second most frequently reported motive $(16 \%)$ is the desire to have sexual intercourse, and the third most frequent motive (12\%) consists in favourable circumstances. The desire to start a partnership with a sexual partner constituted the motive for the first sexual intercourse in $9 \%$ of the respondents, and other $8 \%$ reported curiosity and existence of a permanent relationship. $6 \%$ study participants felt to have been seduced by an experienced sexual partner and $5 \%$ reported consumption of alcohol or drug as a motive. On the contrary, other $5 \%$ felt to be mature for the sexual debut. $3 \%$ men and women made the first coitus because of the partner's willingness. The following answers had $1 \%$ representation: the desire to equal a more experienced friend, the desire to lose virginity and the fear of losing the partner. An important finding consists in the fact that less than $1 \%$ reported rape. Answers suggesting coercion (i was coerced, intimidated) and sex for a reward were not chosen at all. There were $1 \%$ "other" answers, including primarily wedding and infidelity.

It is evident that the respondents' answers are quite scattered. It can be seen that love is the most frequent motive of sexual debut and the first sex is also often linked to partnership. Other respondents start sexual life for different reasons, some of which may contain some risk elements from the perspective of first-level and second-level aspects of sexual health. Up to $44 \%$ motives for sexual debut may contain more or less risky elements of sexual behaviour (curiosity $8 \%$, female partner's willingness $3 \%$, consumption of alcohol or drug $5 \%$, seduction by an experienced partner $6 \%$, favourable circumstances $12 \%$, equalling a more experienced friend $1 \%$, loss of virginity $1 \%$, rape - less than $1 \%$, fear of losing partner $1 \%$, or possibly also desire to have sexual intercourse $6 \%$ ); and it can be also speculated that also the above mentioned fact of existence of partnership could potentially contain hidden forms of pressure as the motive for the first intercourse in a part of the respondents, but that would require a more detailed quality research. In relation to violence, although the respondents did not state coercion as the motive of the first sexual intercourse, different other answers suggest some forms of pressure (loss of losing partner, seduction by experienced partner, etc.). And it is important to state that rape was also reported as the motive for the first sex. 
Table 1 Descriptive statistics: motives for first sex

\begin{tabular}{|l|r|r|}
\hline \multirow{2}{*}{ Variable } & \multicolumn{2}{|c|}{ Descriptive Statistics (SK CZ } \\
\cline { 2 - 3 } & Mode & $\begin{array}{c}\text { Frequency } \\
\text { of Mode }\end{array}$ \\
\hline Var163 & 10,00000 & 198 \\
\hline
\end{tabular}

\section{Diagram 1 Motives for first sex}

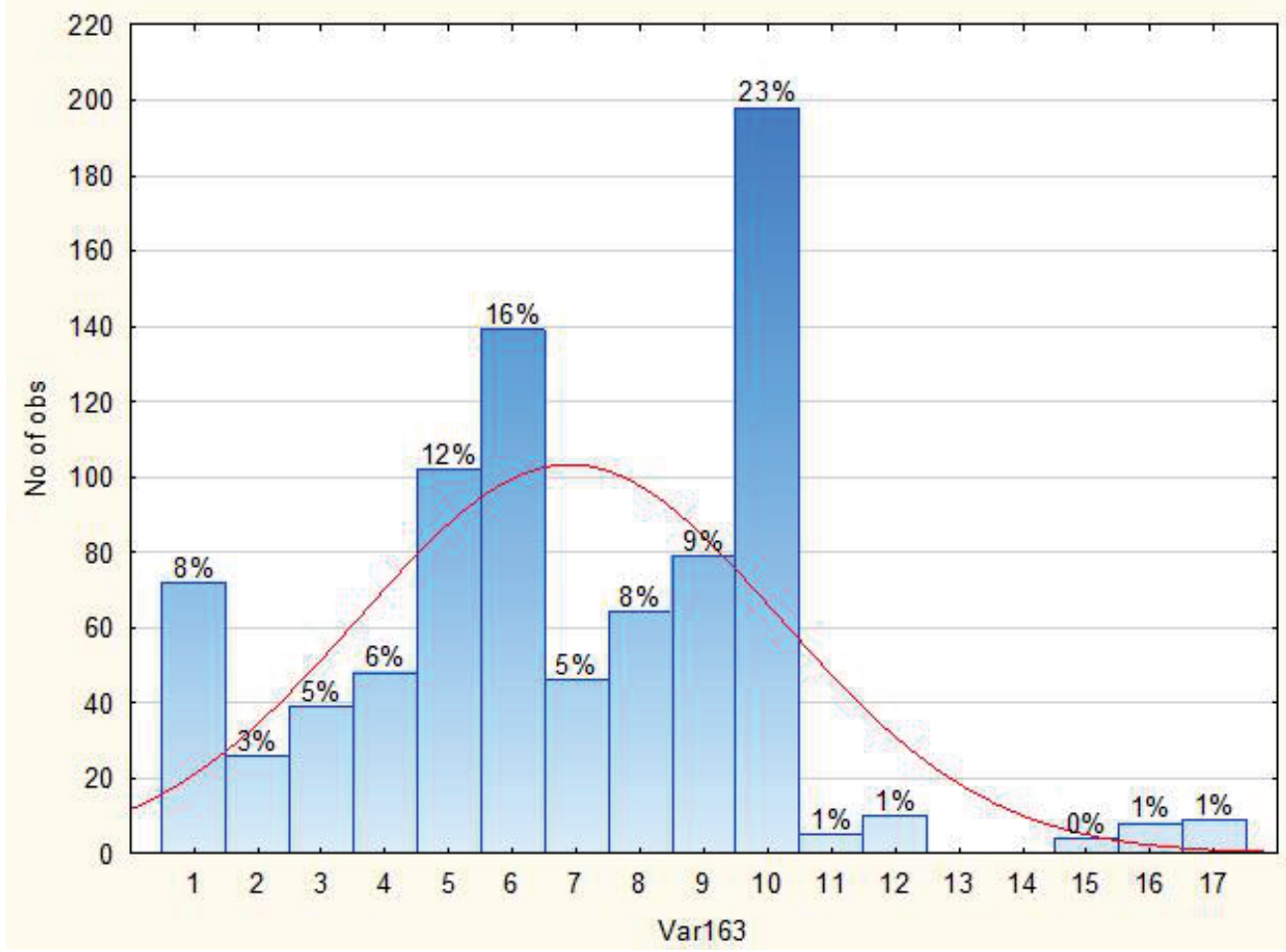

Legend: Motives for first sexual intercourse: 1 - curiosity, 2 - partner's willingness, 3 - consumption of alcohol, drug, 4 - I was seduced by experienced partner, 5 - favourable circumstances, 6 - desire to have sex, 7 - I was mature already, 8 - existence of permanent relationship, 9-desire to start partnership with sexual partner, 10 - love to partner, 11 - I wanted to equal more experienced friends, 12 - I wanted to lose virginity, 13 - I consented to sex for promised reward, 14 - I was coerced / intimidated, 15 - I was raped, 16 - I didn't want to lose my partner, 17 - other motive. Comment: The legend is related also to the remaining diagrams and tables in the text.

\section{Motives for the first coitus by genders}

The study ascertained also the differences in the motives for the first sexual intercourse from the perspective of the respondents' gender. The results of Mann-Whitney $U$ test, shown in table No. 2, prove statistically significant differences. 
The data analysis (tables and diagrams No. 2.1 to 2.3) shows that the most female respondents reported love to the partner as the motive of the first coitus $(27 \%-f)$, while the men stated love as the third most frequent answer $(14 \%-m)$. The men's most frequent answer reported the desire to have sex $(25 \%-m)$, while the women stated it as the second most frequent motive $(13 \%-f)$. For better clarity, table 2.3 lists the motives for the first sex by order of incidence, from the most frequent to the least frequent, separately for male and female respondents.

Although a relative diversity of the data must be considered, the comparison of male and female motives for starting sexual life shows that fear of loss of partner as the motive for the first sex was not stated by men at all and that the female respondents, as compared to male respondents, state more frequently the motives like love and partnership.

Men, as compared to women, state more frequently the following motives to start sexual life: desire to have sex, favourable circumstances, seduction by more experienced partner or partner's willingness.

On the other hand, the motives like curiosity and consumption of alcohol or drug (as well as the lowly represented motives (1\% or less): feeling of social obligation, rape) were reported with the same frequency regardless of the respondents' gender.

The above stated data can be interpreted from the perspective of prevailing gender stereotypes, which is confirmed also by Bianchi's (2001) findings, showing that a strong influence of the family and of traditional ideas of asymmetric division of roles among men and women persists in Slovakia, which is reflected also in the area of sexuality.

Table 2 Results of Mann-Whitney U test: motives for first sex - comparison from the perspective of respondents' gender

\begin{tabular}{|c|c|c|c|c|c|c|c|}
\hline \multirow[b]{2}{*}{ variable } & \multicolumn{7}{|c|}{$\begin{array}{l}\text { Mann-Whitney U Test (w/ continuity correction) (SK CZ) } \\
\text { By variable Var4 } \\
\text { Marked tests are significant at } p<, 05000\end{array}$} \\
\hline & \begin{tabular}{|c|}
$\begin{array}{c}\text { Rank Sum } \\
\text { Group } 1\end{array}$ \\
\end{tabular} & $\begin{array}{c}\text { Rank Sum } \\
\text { Group } 2\end{array}$ & $U$ & $Z$ & p-value & $\begin{array}{c}\mathrm{Z} \\
\text { adjusted }\end{array}$ & $p$-value \\
\hline Var163 & 269167,5 & 91657,5 & 59526,5 & 4,85504 & 0,000001 & 4,9071 & 0,000001 \\
\hline
\end{tabular}


Table 2.1 Descriptive statistics: motives for first sex - women

\begin{tabular}{|l|c|c|}
\hline \multirow{2}{*}{ Variable } & \multicolumn{2}{|c|}{ Descriptive Statistics (F SK CZ } \\
\cline { 2 - 3 } & Mode & $\begin{array}{c}\text { Frequency } \\
\text { of Mode }\end{array}$ \\
\hline Var163 & 10,00000 & 163 \\
\hline
\end{tabular}

Diagram 2.1 Motives for first sex - women

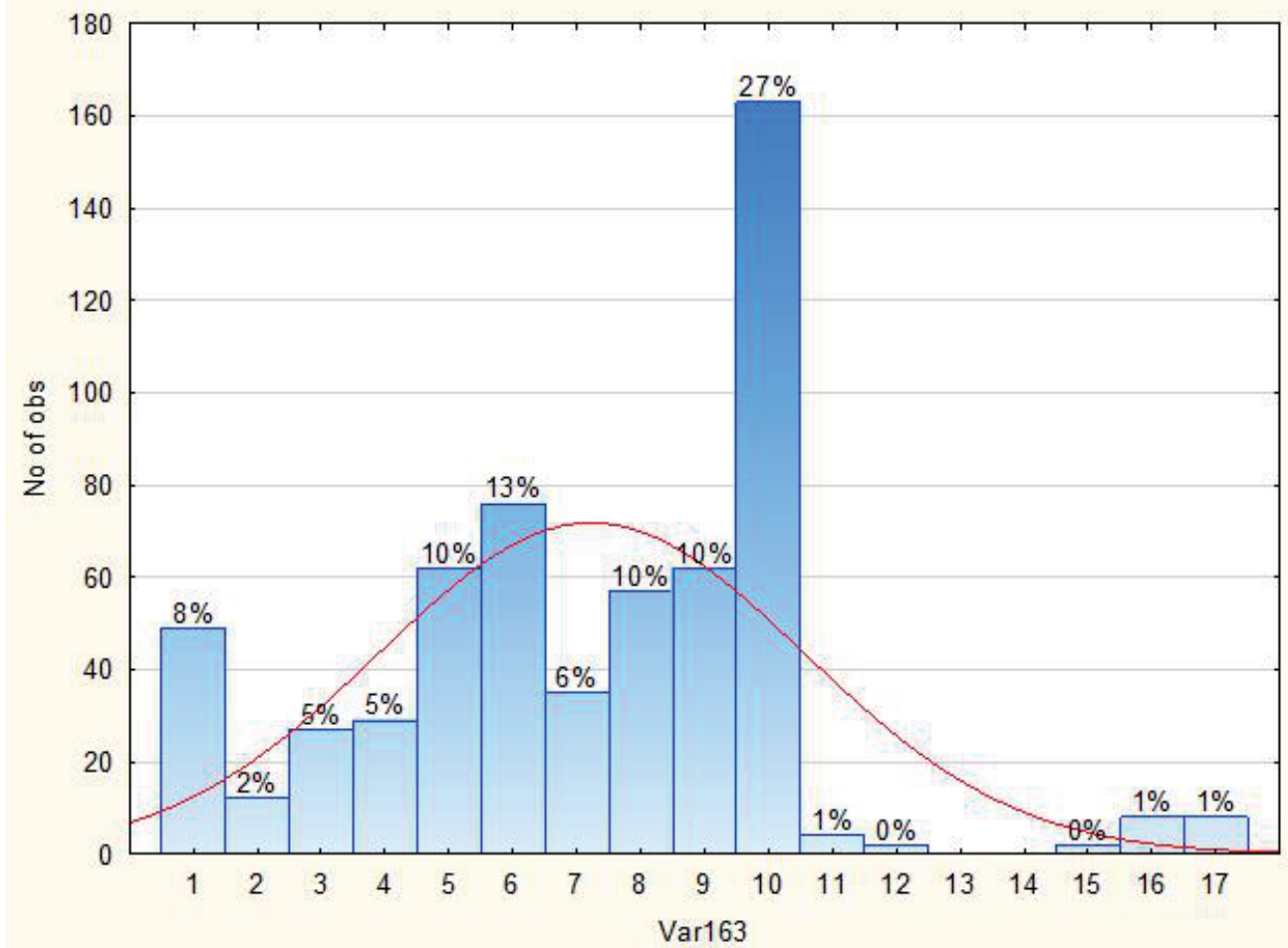


Table 2.2 Descriptive statistics: motives for first sex - men

\begin{tabular}{|c|c|c|}
\hline \multirow[b]{2}{*}{ Variable } & \multicolumn{2}{|c|}{ Descriptive Statistics (M SK CZ } \\
\hline & Mode & $\begin{array}{c}\text { Frequency } \\
\text { of Mode }\end{array}$ \\
\hline Var163 & 6,000000 & 63 \\
\hline
\end{tabular}

\section{Diagram 2.2 Motives for first sex - men}

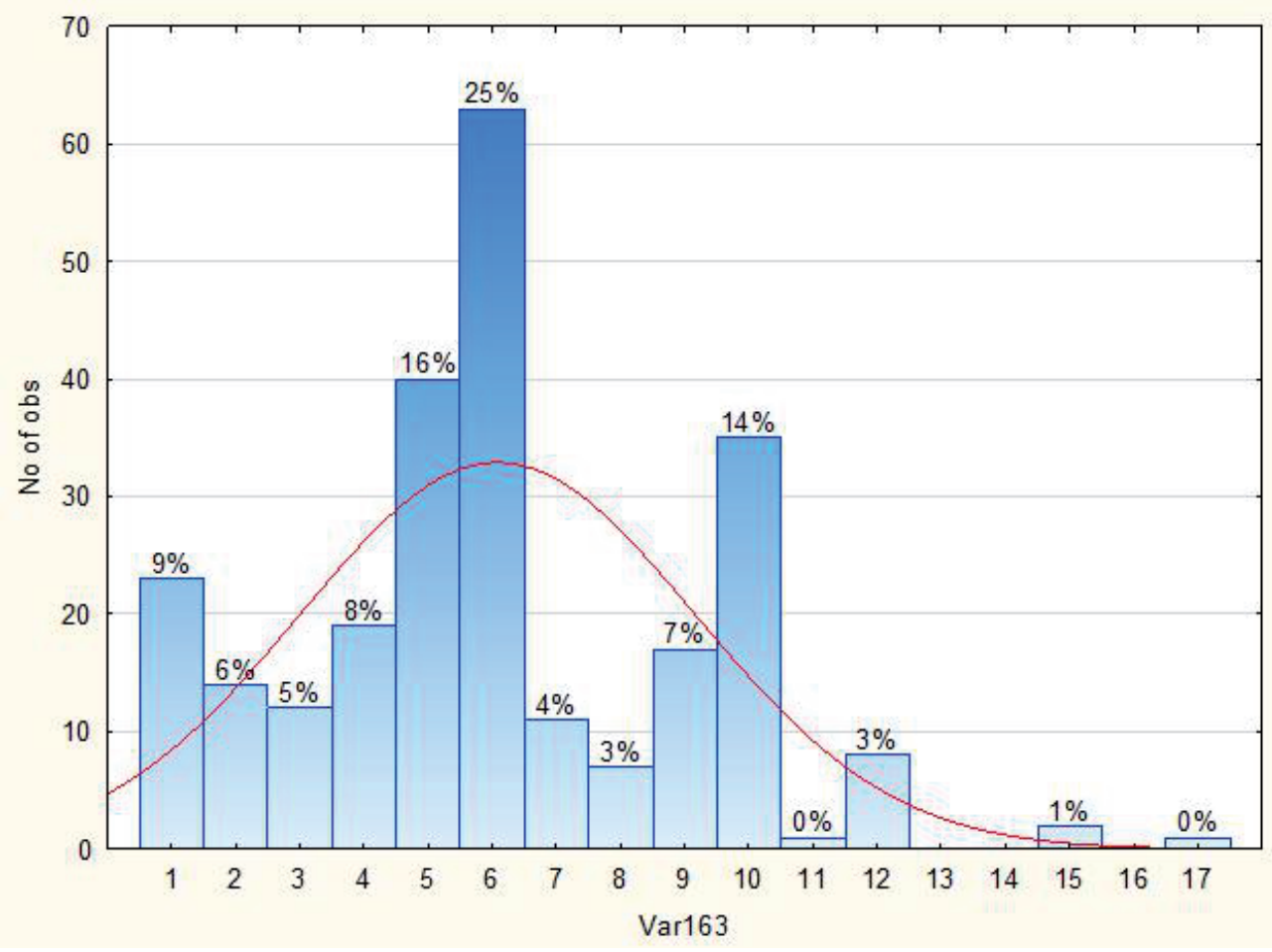

Table 2.3 Comparison of motives for first sex in female and male respondents (shown by order of incidence)

\begin{tabular}{|c|l|c|l|c|}
\hline Order & WOMEN & $\%$ & MEN & $\%$ \\
\hline 1. & love to partner & 27 & desire to have sex & 25 \\
\hline 2. & desire to have sex & 13 & favourable circumstances & 16 \\
\hline 3. & favourable circumstances & 10 & love to partner & 14 \\
\hline 4. & $\begin{array}{l}\text { desire to start partnership with } \\
\text { sexual partner }\end{array}$ & 10 & curiosity & 9 \\
\hline
\end{tabular}




\begin{tabular}{|c|l|c|l|c|}
\hline Order & WOMEN & $\%$ & MEN & $\%$ \\
\hline 5. & $\begin{array}{l}\text { existence of permanent } \\
\text { relationship }\end{array}$ & 10 & $\begin{array}{l}\text { seduction by experienced } \\
\text { partner }\end{array}$ & 8 \\
\hline 6. & curiosity & 8 & $\begin{array}{l}\text { desire to start partnership with } \\
\text { sexual partner }\end{array}$ & 7 \\
\hline 7. & I was mature already & 6 & partner's willingness & 6 \\
\hline 8. & seduction by experienced partner & 5 & consumption of alcohol, drug & 5 \\
\hline 9. & consumption of alcohol, drug & 5 & I was mature already & 4 \\
\hline 10. & partner's willingness & 2 & I wanted to lose virginity & 3 \\
\hline 11. & I didn't want to lose my partner & 1 & $\begin{array}{l}\text { existence of permanent } \\
\text { relationship }\end{array}$ & 3 \\
\hline 12. & other motive & 1 & I was raped & 1 \\
\hline 13. & $\begin{array}{l}\text { I wanted to equal more experi- } \\
\text { enced friends }\end{array}$ & 1 & $\begin{array}{l}\text { I wanted to equal more } \\
\text { experienced friends }\end{array}$ & $\begin{array}{c}\text { less } \\
\text { than } 1\end{array}$ \\
\hline 14. & I wanted to lose virginity & less & than 1 & other motive \\
\hline 15. & I was raped & $\begin{array}{l}\text { less } \\
\text { than } 1\end{array}$ & & than 1 \\
\hline
\end{tabular}

\section{Motives of sexual debut in Slovak-Czech comparison}

As for the description of the differences in the motives of the first coitus from the perspective of Czech or Slovak nationality, table No. 3.1 shows the results of MannWhitney $U$ test, without statistically significant difference between the answers of the respondents from the Czech or the Slovak Republic.

The diagrams and tables No. 3.1 and 3.2 show that both the Czech and the Slovak respondents reported love to partner as the most frequent motive to start sexual life, followed by desire to have sexual intercourse, and the third most frequent answer consisted in favourable circumstances. A difference in the answers can be seen only in the motive "desire to start partnership with sexual partner" - it was stated by $8 \%$ respondents from the Slovak Republic and up to $12 \%$ respondents from the Czech Republic. The answers to this item are also relatively scattered, both in Czech and in Slovak respondents. 
Table 3 Results of Mann-Whitney $U$ test: motives for first sex - comparison from the perspective of Slovak and Czech nationality

\begin{tabular}{|c|c|c|c|c|c|c|c|}
\hline \multirow[b]{2}{*}{ variable } & \multicolumn{7}{|c|}{$\begin{array}{l}\text { Mann-Whitney U Test (w/ continuity correction) (SK CZ) } \\
\text { By variable Var2 } \\
\text { Marked tests are significant at } p<, 05000\end{array}$} \\
\hline & \begin{tabular}{|c|} 
Rank Sum \\
Group 1 \\
\end{tabular} & $\begin{array}{l}\text { Rank Sum } \\
\text { Group } 2\end{array}$ & $U$ & $z$ & p-value & $\begin{array}{c}\mathrm{Z} \\
\text { adjusted }\end{array}$ & $\mathrm{p}$-value \\
\hline Var163 & 244155,5 & 116669,5 & 78166,5 & 0,3149 & 0,752825 & 0,3183 & 0,750261 \\
\hline
\end{tabular}

3.1 Descriptive statistics: motives for first sex - Slovak Rep.

\begin{tabular}{|l|c|c|}
\hline \multirow{2}{*}{ Variable } & \multicolumn{2}{|c|}{ Descriptive Statistics (SK) } \\
\cline { 2 - 3 } & Mode & $\begin{array}{c}\text { Frequency } \\
\text { of Mode }\end{array}$ \\
\hline Var163 & 10,00000 & 138 \\
\hline
\end{tabular}

Diagram 3.1 Motives for first sex - Slovak Rep.

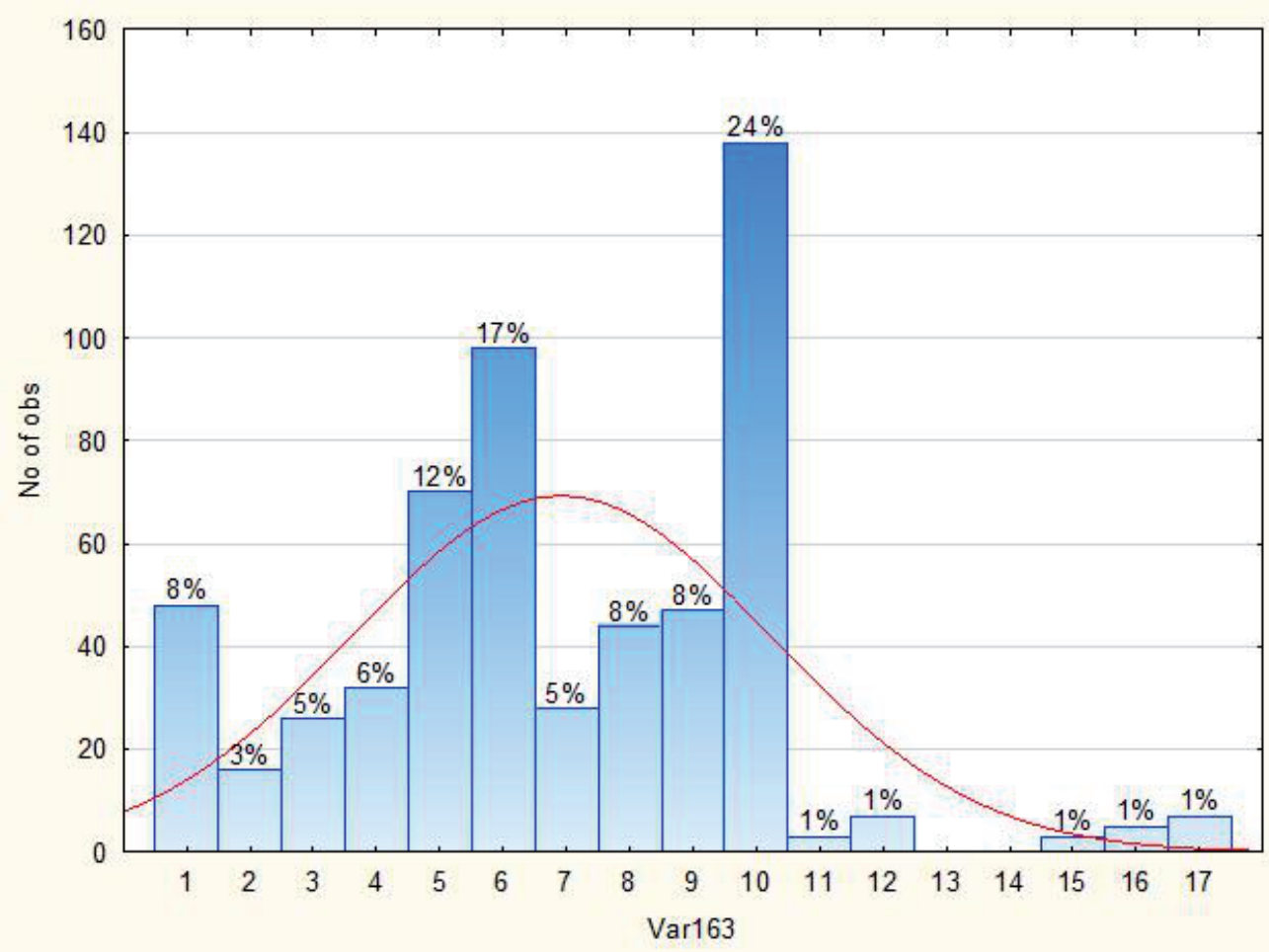


Table 3.2 Descriptive statistics: motives for first sex - Czech Rep.

\begin{tabular}{|l|c|c|}
\hline \multirow{2}{*}{ Variable } & \multicolumn{2}{|c|}{ Descriptive Statistics (CZ) } \\
\cline { 2 - 3 } & Mode & $\begin{array}{c}\text { Frequency } \\
\text { of Mode }\end{array}$ \\
\hline Var163 & 10,00000 & 60 \\
\hline
\end{tabular}

Diagram 3.2 Motives for first sex - Czech Rep.

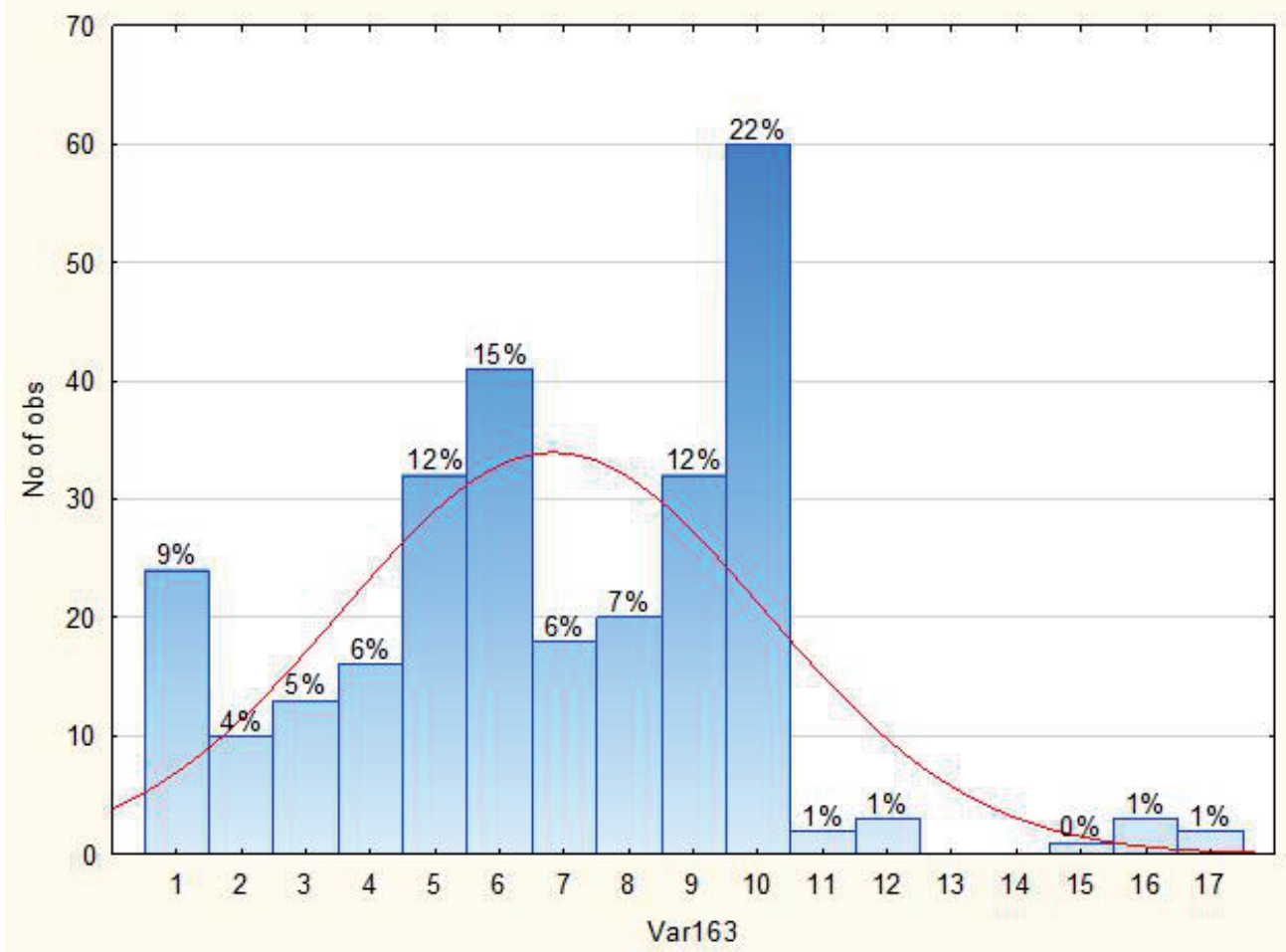

\section{Motives for sexual debut in intergeneration perspective}

As for the differences in the motives for the first sexual intercourse from the perspective of the respondent's age, we created three age categories - persons of younger adult age (under thirty years), middle adult age (31-40 years) and older adult age (over 41 years). The results of Kruskal-Wallis test (table No. 4) show that no statistically significant difference was found at $5 \%$ level of significance in the issue of the motives of sexual debut with respect to the three aged categories compared.

Analogically to the comparison of the motives of the first sex by the respondents' gender or Czech or Slovak nationality, the specific results, separated for the three age categories 
observed, are presented in tables and diagrams No. 4.1-4.3. Love is stated as motive for the first sex most frequently, regardless of the age categories. The second most frequent motive is desire to have sex in respondents of younger (16\%) and older (18\%) adult age; the respondents of middle adult age chose favourable circumstances at the second place (20\%). The third most frequent motive of the first sexual intercourse is: favourable circumstances in respondents of younger adult age (11\%), desire to have sex in middle adult category (16\%) and curiosity in older adult age (15\%).

Although no statistically significant differences were found in the motives of the first sexual intercourse from the perspective of the three age categories observed, the percentage of the answers suggests that persons of younger adult age stated more frequently, as compared to the other age categories, the consumption of alcohol or drugs and own maturity as motive of sexual debut, while stating less frequently seduction by a more experienced partner. Persons of middle adult age, as compared to the remaining two age categories, stated more frequently favourable circumstances and less frequently own maturity as the motive for sexual debut. The respondents of older adult age, as compared to the other age categories, reported most frequently curiosity as the motive to start sexual life and - on the other hand - less frequently the existence of a permanent relationship and the desire to start partnership with a sexual partner.

Table 4 Results of Kruskal-Wallis test: motives for first sex - comparison from the perspective of age categories

\begin{tabular}{|c|c|c|c|}
\hline \multirow[b]{2}{*}{$\begin{array}{l}\text { Depend.: } \\
\text { Var163 }\end{array}$} & \multicolumn{3}{|c|}{$\begin{array}{l}\text { Multiple Comparisons p values (2-tailed); Var163 (SK CZ } \\
\text { Independent (grouping) variable: Var1 } \\
\text { Kruskal-Wallis test: H ( } 2 \text { ) =,9972399 p =,6074 }\end{array}$} \\
\hline & $\begin{array}{c}1 \\
R: 425,78\end{array}$ & $\begin{array}{c}2 \\
R: 437,51\end{array}$ & $\begin{array}{c}3 \\
\text { R:396,25 }\end{array}$ \\
\hline 1 & & 1,000000 & 1,000000 \\
\hline 2 & 1,000000 & & 1,000000 \\
\hline 3 & 1,000000 & 1,000000 & \\
\hline
\end{tabular}

Legend: 1 -younger adult age, 2 - middle adult age, 3 - older adult age 
Table 4.1 Descriptive statistics: motives for first sex - younger adult age

\begin{tabular}{|l|c|r|}
\hline \multirow{2}{*}{ Variable } & \multicolumn{2}{|c|}{ Descriptive Statistics (Y SK CZ) } \\
\cline { 2 - 3 } & Mode & $\begin{array}{c}\text { Frequency } \\
\text { of Mode }\end{array}$ \\
\hline Var163 & 10,00000 & 162 \\
\hline
\end{tabular}

Diagram 4.1 Motives for first sex - younger adult age

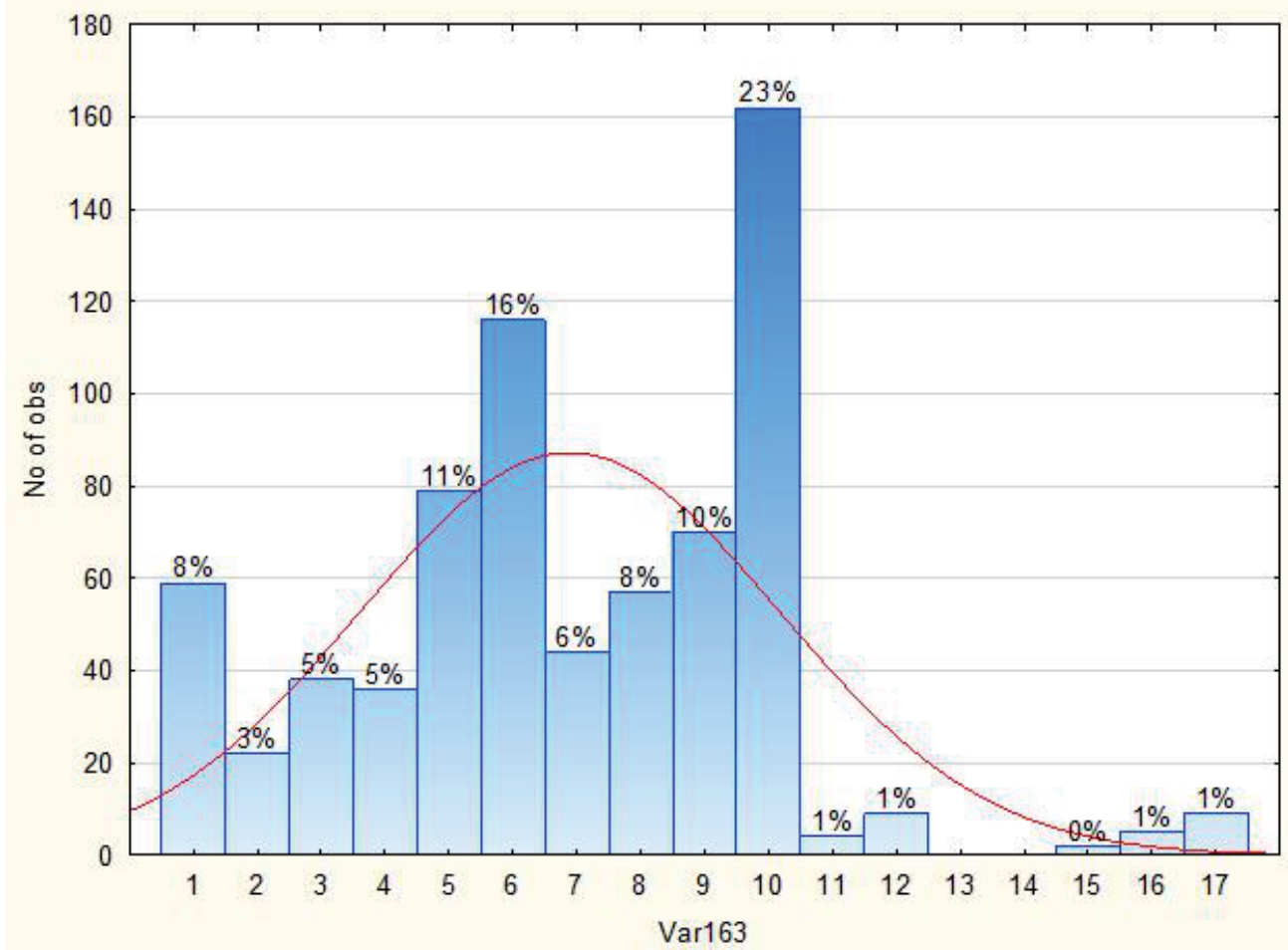


Table 4.2 Descriptive statistics: motives for first sex - middle adult age

\begin{tabular}{|l|c|c|}
\hline \multirow{2}{*}{ Variable } & \multicolumn{3}{|c|}{ Descriptive Statistics (M SK CZ } \\
\cline { 2 - 3 } & Mode & $\begin{array}{c}\text { Frequency } \\
\text { of Mode }\end{array}$ \\
\hline Var163 & 10,00000 & 21 \\
\hline
\end{tabular}

Diagram 4.2 Motives for first sex - middle adult age

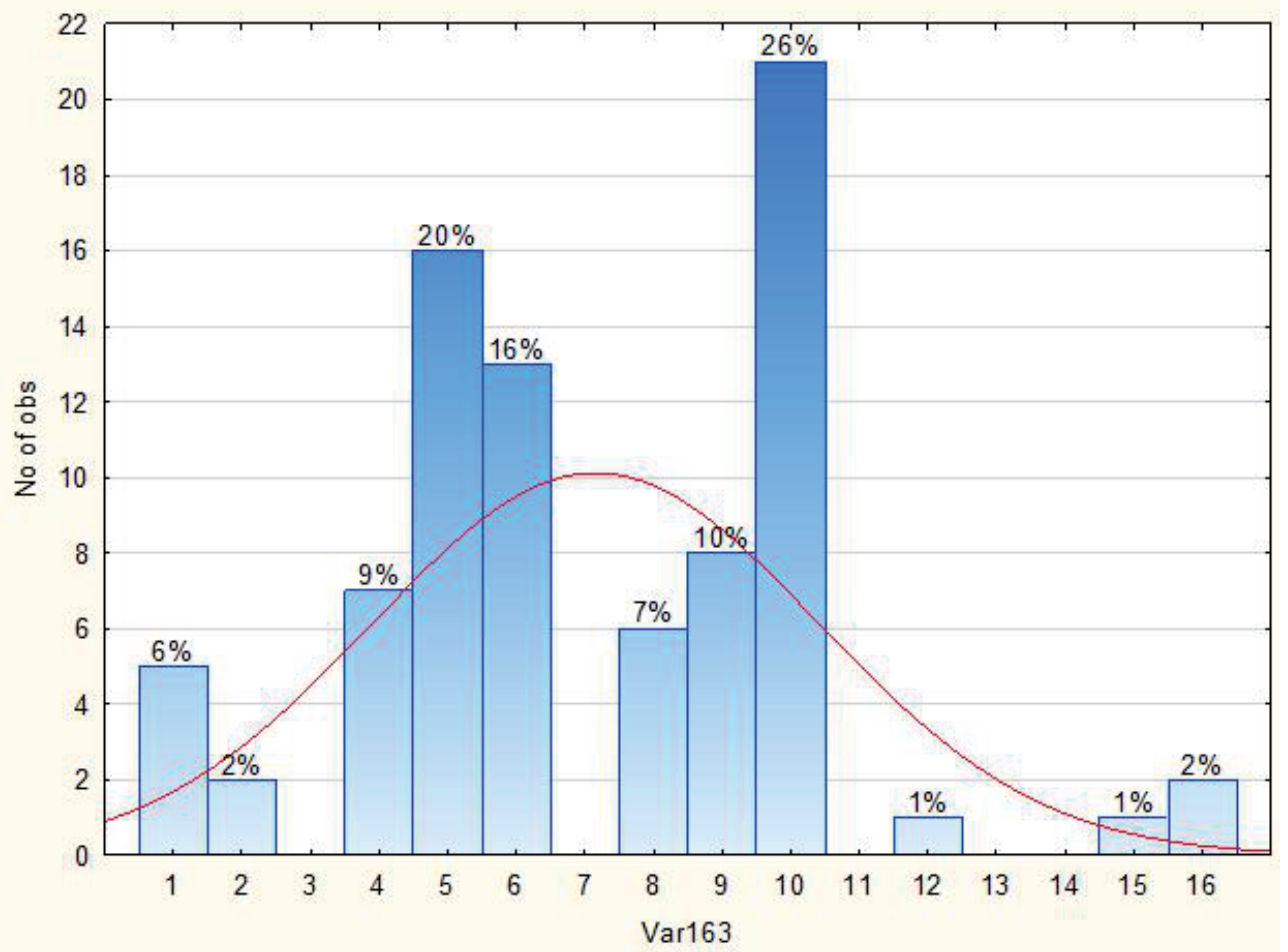


Table 4.3 Descriptive statistics: motives for first sex - older adult age

\begin{tabular}{|l|c|c|}
\hline \multirow{2}{*}{ Variable } & \multicolumn{2}{|c|}{ Descriptive Statistics (O SK CZ) } \\
\cline { 2 - 3 } & Mode & $\begin{array}{c}\text { Frequency } \\
\text { of Mode }\end{array}$ \\
\hline Var163 & 10,00000 & 15 \\
\hline
\end{tabular}

Diagram 4.3 Motives for first sex - older adult age

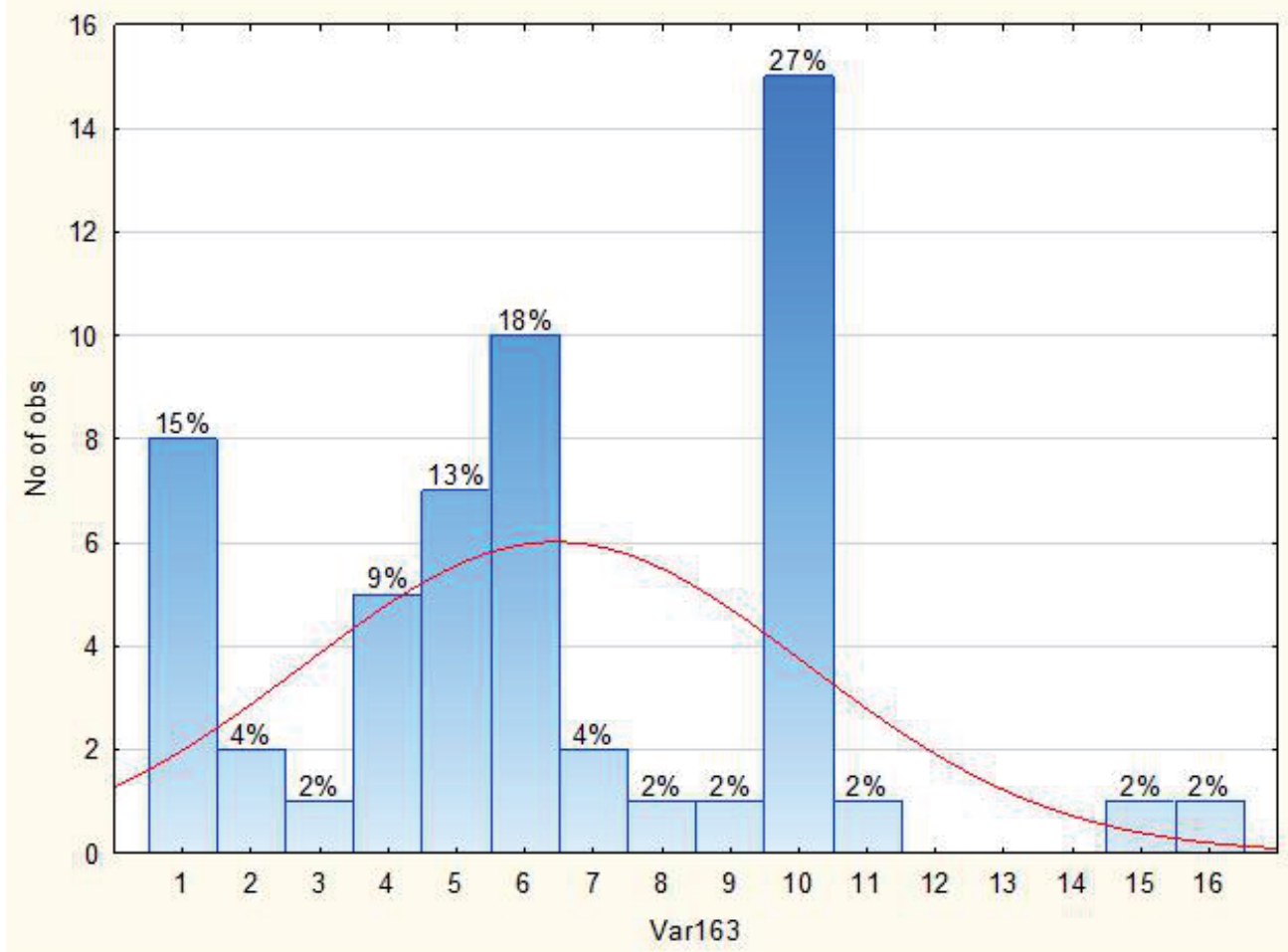

\section{Motives for the first sex from the perspective of moral preferences}

Based on Knox and Schacht (2011), we divided the respondents into three main categories by their prevailing moral systems - absolutism, relativism and hedonism. The following tables and diagrams No. 5 show the answers to the question about the motives for the first sexual intercourse only for the respondents who could be classified in one of the above stated three groups, and the analysis does not include the answers of those classified in the "mixed" group. Thus the data interpretation must consider the fact that the number of respondents is reduced in the analysis. 
The results of Kruskal-Wallis test shown in table No. 5 prove that, from the perspective of the three observed moral preference groups, the answers to the question about the motives for the first sex significantly differ between relativists and hedonists.

The most frequent motive for the first sex stated by relativists (and absolutists) is love to the partner $(24 \%-r, 26 \%-a)$, while hedonists $(24 \%-h)$ state the desire to have sex (tables and diagrams No. 5.1-5.3). The second most frequent motive stated by the relativists is the desire to have sex (17\%), while the hedonists state love to the partner and favourable circumstances (16\%) and the absolutists the existence of a permanent relationship and favourable circumstances (17\%). The third most frequent motive of the first coitus of the relativists consists in favourable circumstances (14\%), while the hedonists state curiosity (11\%) and the absolutists curiosity and desire to have sex (11\%).

The relativists, as compared to the other groups, stated most frequently seduction by a more experienced partner and desire to start partnership with a sexual partner, and less frequently curiosity. The hedonists stated more frequently desire to have sex and less frequently love to the partner. The absolutists stated more frequently the existence of a permanent relationship and less frequently consumption of alcohol or drug, seduction by an experienced partner and desire to have sex.

Table 5 Results of Kruskal-Wallis test: motives for first sex - comparison from the perspective of moral preferences

\begin{tabular}{|l|r|r|r|}
\hline \multirow{2}{*}{ Depend.: } & \multicolumn{3}{|l|}{$\begin{array}{l}\text { Multiple Comparisons p values (2-tailed); Var163 (moral SKCZ } \\
\text { Independent (grouping) variable: Var363 } \\
\text { Kruskal-Wallis test: } \mathrm{H}(2)=8,853540 \mathrm{p}=, 0120\end{array}$} \\
\cline { 2 - 5 } Var163 & $\begin{array}{c}1 \\
\mathrm{R}: 218,10\end{array}$ & $\begin{array}{c}2 \\
\mathrm{R}: 222,81\end{array}$ & $\mathrm{R}: 181,57$ \\
\hline 1 & & 1,000000 & 0,014109 \\
\hline 2 & 1,000000 & & 0,208736 \\
\hline 3 & 0,014109 & 0,208736 & \\
\hline
\end{tabular}

Legend: Moral preferences: 1 - relativism, 2 - absolutism, 3 - hedonism 
Table 5.1 Descriptive statistics: motives for first sex - relativists

\begin{tabular}{|l|c|c|}
\hline \multirow{2}{*}{ Variable } & \multicolumn{2}{|c|}{ Descriptive Statistics (R SKCZ } \\
\cline { 2 - 4 } & Mode & $\begin{array}{c}\text { Frequency } \\
\text { of Mode }\end{array}$ \\
\hline Var163 & 10,00000 & 60 \\
\hline
\end{tabular}

Diagram 5.1 Motives for first sex - relativists

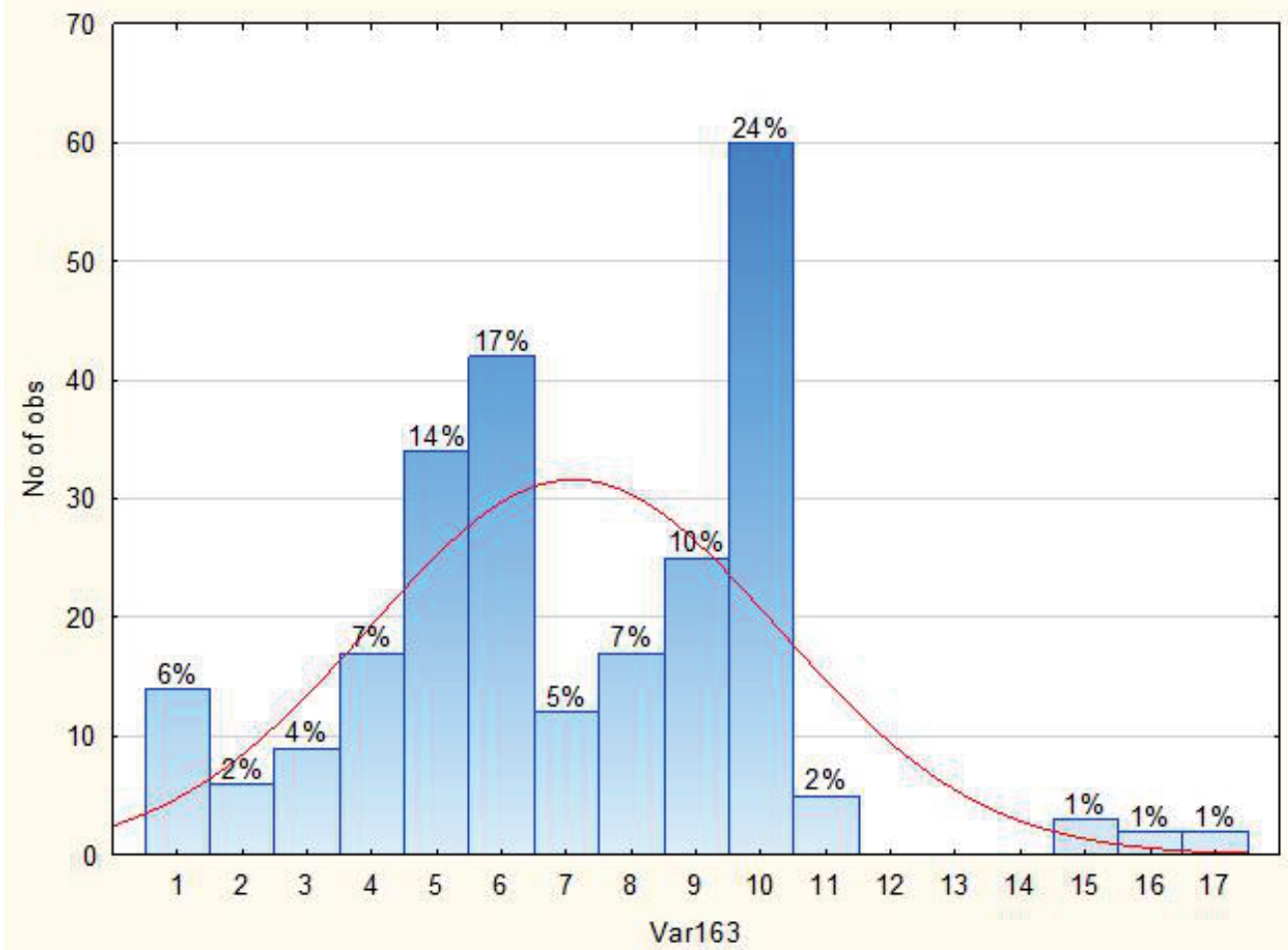


Table 5.2 Descriptive statistics: motives for first sex - absolutists

\begin{tabular}{|l|c|c|}
\hline \multirow{2}{*}{ Variable } & \multicolumn{3}{|c|}{ Descriptive Statistics (A SKCZ } \\
\cline { 2 - 3 } & Mode & $\begin{array}{c}\text { Frequency } \\
\text { of Mode }\end{array}$ \\
\hline Var163 & 10,00000 & 9 \\
\hline
\end{tabular}

Diagram 5.2 Motives for first sex - absolutists

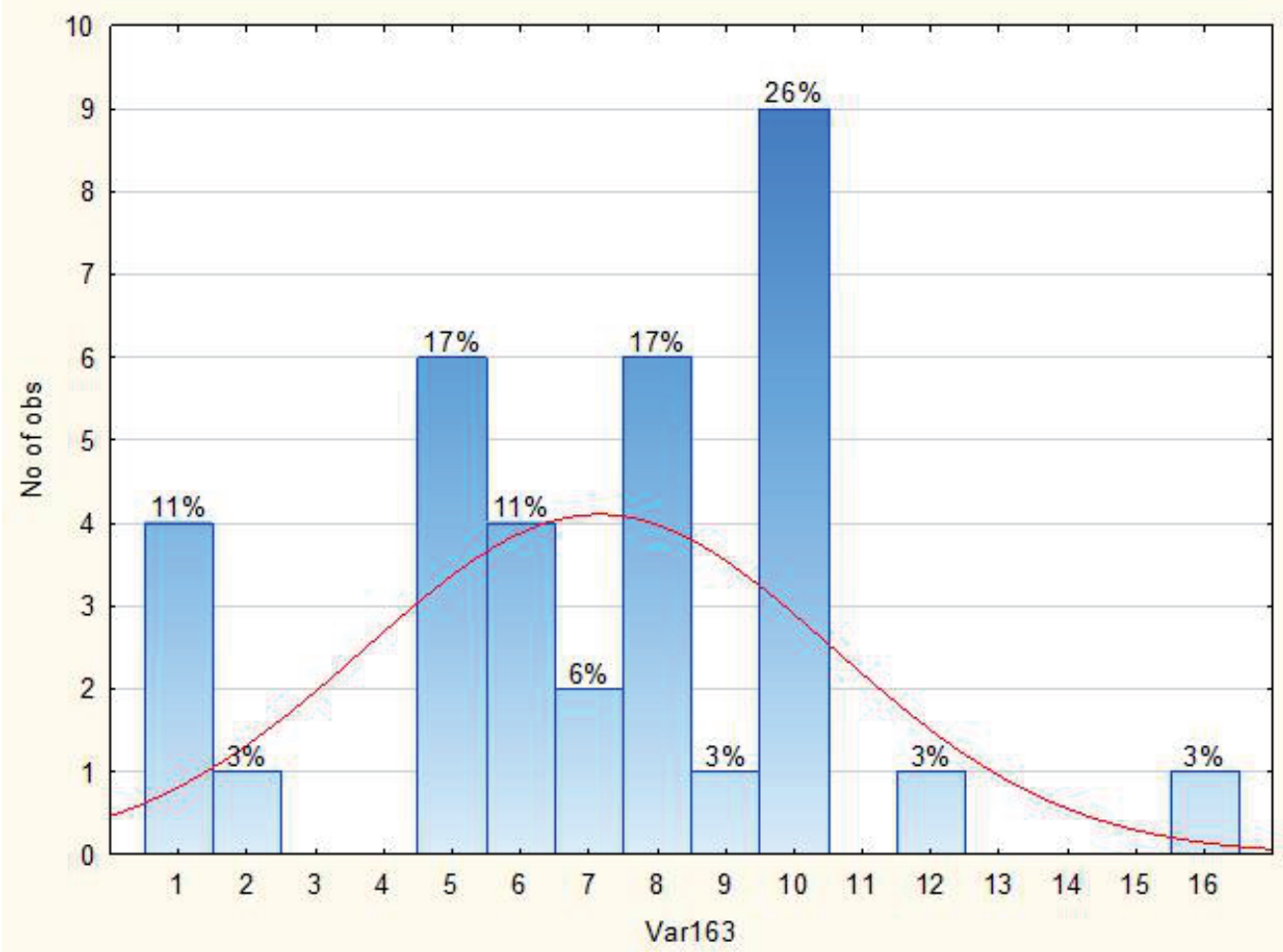


Table 5.3 Descriptive statistics: motives for first sex - hedonists

\begin{tabular}{|l|c|c|}
\hline \multirow{2}{*}{ Variable } & \multicolumn{2}{|c|}{ Descriptive Statistics (H SKCZ } \\
\cline { 2 - 4 } & Mode & $\begin{array}{c}\text { Frequency } \\
\text { of Mode }\end{array}$ \\
\hline Var163 & 6,000000 & 31 \\
\hline
\end{tabular}

\section{Diagram 5.3 Motives for first sex - hedonists}

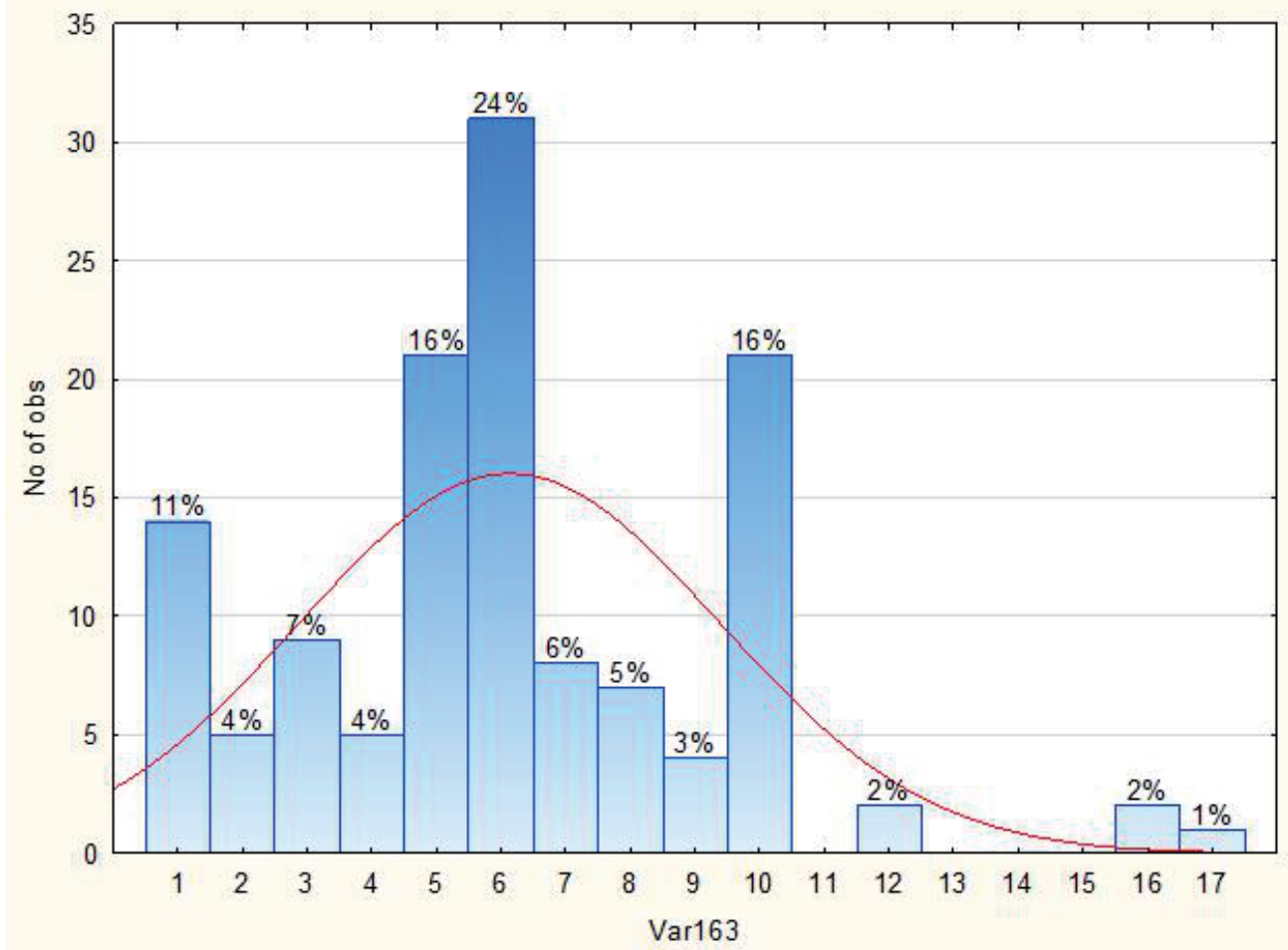

\section{Motives for the first sex from the perspective of religious belief}

Without a more detailed analysis and description, but also because of the relevance from the perspective of moral preferences, we also state the results of the differences in the motives for the first sex from the perspective of religious belief.

The results of Kruskal-Walls test, shown in table No. 6.2, suggest that from the perspective of strength of belief, no statistically significant differences at $5 \%$ level of significance were found, but from the perspective of religious belief (tab. No. 6.1), there are statistically significant differences in the answers of the respondents who consider themselves 
Catholic-Protestant believers going occasionally to the church, and of the respondents who consider themselves atheists (disbelievers).

Table 6.1 Results of Kruskal-Wallis test: motives for first sex - comparison from the perspective of religious belief

\begin{tabular}{|c|c|c|c|c|c|}
\hline \multirow[b]{2}{*}{$\begin{array}{l}\text { Depend.: } \\
\text { Var163 }\end{array}$} & \multicolumn{5}{|c|}{$\begin{array}{l}\text { Multiple Comparisons p values (2-tailed); Var163 (SK CZ) } \\
\text { Independent (grouping) variable: Var6 } \\
\text { Kruskal-Wallis test: } \mathrm{H}(4)=10,57395 \mathrm{p}=, 0318\end{array}$} \\
\hline & \begin{tabular}{c|c|} 
\\
$R: 435,47$ \\
\end{tabular} & $\begin{array}{c}2 \\
R: 450,03\end{array}$ & $\begin{array}{c}3 \\
\text { R: } 409,00\end{array}$ & $\begin{array}{c}4 \\
\mathrm{R}: 371,69 \\
\end{array}$ & $\begin{array}{c}5 \\
R: 420,55 \\
\end{array}$ \\
\hline 1 & & 1,000000 & 1,000000 & 0,330292 & 1,000000 \\
\hline 2 & 1,000000 & & 0,591339 & 0,026181 & 1,000000 \\
\hline 3 & 1,000000 & 0,591339 & & 1,000000 & 1,000000 \\
\hline 4 & 0,330292 & 0,026181 & 1,000000 & & 1,000000 \\
\hline 5 & 1,000000 & 1,000000 & 1,000000 & 1,000000 & \\
\hline
\end{tabular}

Legend: Religious belief - question: I consider myself: 1 - Catholic-Protestant believer - I go regularly to the church; 2 - Catholic-Protestant believer - I go occasionally to the church; 3 - Catholic-Protestant believer I don't go to the church; 4 - atheist-disbeliever; 5 - other.

Table 6.2 Results of Kruskal-Wallis test: motives for first sex - comparison from the perspective of strength of belief

\begin{tabular}{|c|c|c|c|c|c|}
\hline \multirow[b]{2}{*}{$\begin{array}{l}\text { Depend.: } \\
\text { Var163 }\end{array}$} & \multicolumn{5}{|c|}{$\begin{array}{l}\text { Multiple Comparisons p values (2-tailed); Var163 (SK CZ) } \\
\text { Independent (grouping) variable: Var7 } \\
\text { Kruskal-Wallis test: } \mathrm{H}(4)=6,651783 p=, 1555\end{array}$} \\
\hline & $\begin{array}{c}1 \\
\text { R: } 441,69 \\
\end{array}$ & $\begin{array}{c}2 \\
\text { R: } 423,91 \\
\end{array}$ & $\begin{array}{c}3 \\
\text { R:552,61 } \\
\end{array}$ & $\begin{array}{c}4 \\
R: 348,82 \\
\end{array}$ & $\begin{array}{c}5 \\
R: 315,68\end{array}$ \\
\hline 1 & & 1,000000 & 1,000000 & 1,000000 & 1,000000 \\
\hline 2 & 1,000000 & & 1,000000 & 1,000000 & 1,000000 \\
\hline 3 & 1,000000 & 1,000000 & & 0,517689 & 0,315904 \\
\hline 4 & 1,000000 & 1,000000 & 0,517689 & & 1,000000 \\
\hline 5 & 1,000000 & 1,000000 & 0,315904 & 1,000000 & \\
\hline
\end{tabular}

Legend: Strength of belief - question: Are you religious? 1 - very strongly; 2 - strongly; 3 - on average; 4 - weekly; 5 - not at all.

\section{Conclusion}

The identified motives of sexual debut show a considerable variedness, which reflects also the diversity in individual sexual and partner curricula and moral and axoiological preferences (for more details see: Marková, 2017a, 2017b).

From the perspective of sexual moral, it must be pointed out that love was stated as the most frequent motive for the first coitus, but still only by one fourth of the 
respondents. Moral structures linking sexuality to partnership can be assumed too (8\%). $5 \%$ respondents see the first sexual intercourse as the result of a natural course of their sexual development, and $8 \%$ respondents see the motive for their first sexual experience in their own maturity or preparedness with respect to the development of the partnership. $16 \%$ respondents see the motive for the first sex in the desire to have it. The above stated findings are in accordance with our preceding findings (Marková, 2015a) suggesting that sex legitimized by love is a dominant moral philosophy of $10 \%$ respondents. At the level of moral approval, sexuality is most frequently linked to partnership based on love, fidelity and confidence, but liberal constructions of sexuality, hedonistic and conservative moral preferences are represented as well.

Further results presented suggest that some respondents start sexual life for reasons that can be considered risky from the perspective of first-level or second-level aspects of sexual health. As Bianchi (2001) found, motives for sexual debut can be identified as pressure to sexual intercourse, consumption of alcohol or drug, favourable circumstances, curiosity, etc. As for their incidence, although such answers are varied, reflect different elements of risk level and can be assessed in different relation frameworks, up to $44 \%$ of the motives for the first sexual intercourse may suggest some risk level (among other things, a serious finding consists in the fact that less than $1 \%$ stated rape as the first sexual experience).

The motives for the first sexual intercourse showed statistically significant differences from the perspective of gender, moral preferences and religious belief; on the other hand, no statistically significant differences were identified from the perspective of Czech or Slovak nationality and age. The results suggest also gender-stereotypic constructing of sexuality, which is in accordance with the statement of many authors (e.g. in Slovakia: Bačová, 2005; Lukšík, 2003; Lukšík \& Supeková 2003; Bosá, 2003a, 2003b; Bosá \& Minarovičová, 2005 etc.) that so called "double moral standard" still survives in the perspective on male and female sexuality.

The acquired research data may suggest some aspects of sexual morals and at the same time serve as a useful tool of sexual education in connection with the support of first-level and second-level aspects of sexual health. As Bianchi (2001), Marková (2007a, 2007b), Rovňanová (2010, 2013, 2014a, 2014b) and other authors state and as our research findings suggest, the sexual education should address the gender-stereotypic and rigid expectations from male and female sexuality, as well as conformity that can be seen in different forms of pressure and decision making about making the first sex, and last but not least in the impulsiveness and situationality related to favourable circumstances, the partner's willingness or consumption of alcohol or drugs. 


\section{References}

Bačová, V. (2005). Ako sa vytvára ženskost': spojenie moci a sebadefinovania. [How to Form Femminity: Connection of Power and Self-Definition]. In J. Cviková, J. Juráňová, \& Ĺ. Kobová (Eds.), Žena nie je tovar: Komodifikácia žien v našej kultúre. [Woman is Not a Commodity] (pp. 173-192). Bratislava: Aspekt.

Bernik, I., \& Hlebec, V. (2003). Erste sexuelle Erfahrungen von Jugendlichen in sieben postsozialistischen Ländern: Eine Vergleichsstudie. Zeitschrift für Sexualforschung, 16(03), 232-246.

Bianchi, G. (2001). Sexuálne zdravie ako kultúrny, sociálny a politický jav. [Sexual Health as Cultural, Social and Political Phenomenon]. In Identita, zdravie a nová paradigma. [Identity, Health and New Paradigm] Human Communication Studies, vol. 7 (pp. 169184). Bratislava: Veda.

Bosá, M. (2003a). Vztáah rodových stereotypov k zodpovednosti v sexuálnom živote. [Relation of Gender Stereotypes to Responsibility in Sexual Life]. In G. Bianchi (Ed.), Upgrade Pre sexuálnu výchovu. [Upgrade for Sex Education] (pp. 53-61). Bratislava: VEDA - KVSBK SAV.

Bosá, M. (2003b). Prečo je tá láska taká tažká?: riziká stereotypného vnímania sexuality. [Why is the Love so Difficult?: risks of stereotypical perception of sexuality]. In J. Cviková, \& J. Juráňová (Eds.) Ružový a modrý svet : Rodové stereotypy a ich dôsledky. [Pink and Blue World: Gender Streotypes and Their Consequences] (pp.114-126). Bratislava: Občan a demokracia [Citizen and Democracy], Aspekt.

Bosá, M., \& Minarovičová, K. (2005). Rodovo citlivá výchova. [Gender Sensitive Upbringing]. Bratislava, EsFem.

Bozon, M., \& Kontula, O. (1998). Sexual initiation and gender in Europe: A cross-cultural analysis of trends in the twentieth century. In Sexual Behaviour and HIV/AIDS in Europe: Comparisons of National Surveys. Social Aspects of AIDS Series (pp. 37-67). London: Taylor \& Francis.

Bundeszentrale Für Gesundheitliche Aufklärung. (2006). Jugendsexualität. Repräsentative Wiederholungsbefragung von 14- bis 17-jährigen und ihren Eltern. Ergebnisse der Repräsentativbefragung aus 2005. Köln: BZgA.

Dannenbeck, C., \& Stich, J. (2005). Sexuelle Erfahrungen im Jugendalter: Aushandlungsprozesse im Geschlechterverhältnis. Eine qualitative Studie im Auftrag der BZgA. Köln: BZgA. 
Knox, D., \& Schacht, C. (2011). M\&F. Wadsworth: WCN.

Koliba, P. (1996). Sexualita mladistvých a sexuální výchova. [Sexuality of Youth and Sexual Education]. Školství [Education System], (43), 3.

Laumann, E. O., Gagnon, J. H., Michael, R. T., \& Michaels, S. (1994). The social organization of sexuality: Sexual Practices in the United States. Chicago: The University of Chicago.

Lukšík, I. (1997). Základné údaje o názoroch, postojoch a správaní sa mládeže na Slovensku v oblastiach: drogy, HIV/AIDS a sexualita podla dotazníkového prieskumu Cadillac'97. [Basic data on the opinions, attitudes and behavior of youth in Slovakia in the following areas: drugs, HIVIAIDS and sexuality according to the Cadillac'97 questionnaire]. own source.

Lukšík, I. (2003). Sexualita a rodovost'. [Sexuality and Gender]. In 11. celostátní kongres k sexuální výchově v České republice. Pardubice 2003. Sborník referátů. [1 $11^{\text {th }}$ National Congress on Sex Education in the Czech Republic. Pardubice 2003. Conference Proceedings] (pp. 88-92). Prague: Společnost pro plánování rodiny a sexuální výchovu $\checkmark$ Praze a Nová tiskárna Pelhřimov [Society for Family Planning and Sex Education in Prague and New Printing House Pelhřimov].

Lukšík, I., \& Supeková, M. (2003). Sexualita a rodovost' v sociálnych a výchovných súvislostiach. [Sexuality and Gender in Social and Educational Connections]. Bratislava: Humanitas.

Marková, D. (2007a). Predmanželská sexualita v kontextoch sexuálnej diverzity a variability. [Premarital Sexuality in Context of Sexual Diversion and Variability]. Bratislava: Regent.

Marková, D. (2007b). Sexuálna výchova na Slovensku v kontextoch diskurzov o sexualite. [Sex Education in Slovakia in Context of Discourse on Sexuality]. In K. Janiš, \& D. Marková, Př́spěvek $k$ základům sexuální výchovy [Contribution to Basics of Sex Education]. (pp. 53-76). Hradec Králové: Gaudeamus.

Marková, D. (2015a). Sexual Morality in Slovakia and the Czech Republic. Ljubljana: KUD Apokalipsa.

Marková, D. (2015b). Moral Values in Sexual and Partner Relationships. Ljubljana: KUD Apokalipsa.

Martin, K. A. (2002). "I couldn't ever picture myself having sex...": Gender Differences in Sex and Sexual Subjectivity. In Sexuality and Gender (pp. 142-166). Malden - Oxford: Blackwell Publishers. 
Narring, F., Wydler, H., \& Michaud, P. A. (2000). First sexual intercourse and contraception: a cross-sectional survey on the sexuality of 16-20-year-olds in Switzerland. Schweizerische Medizinische Wochenschrift, 130(40), 1389-1398.

Nöstlinger, Ch., \& Wimmer-Puchinger, B. (1994). Geschützte Liebe - Jugendsexualität und AIDS. Wien: J \& V.

Rovňanová, L. (2010). Výchova k manželstvu a rodičovstvu v kontexte školskej reformy. [Education for Marriage and Parenthood in Context of School Reform]. In Sexuality IV. Zborník vedeckých príspevkov [Sexuality IV. Almanac of Scientific Contributions] (pp. 248-280). Bratislava: Comenius University.

Rovňanová, L. (2013). Sexuálna výchova v kontexte ludských práv - príklad dobrej praxe. [Sex Education in Context of Human Rights - example of good practice]. In Sexuality VI. Zborník vedeckých príspevkov. [Sexuality VI. Almanac of Scientific Contributions] (pp. 322-341). Banská Bystrica: Matej Bel University.

Rovňanová, L. (2014a). Výchova k manželstvu a rodičovstvu a etike intímnych vztáahov 2. čast.' [Education for Marriage and Parenthood and Ethics of Intimate Relationships - Part 2]. Bratislava: Metodicko-pedagogické centrum [Methodological and Pedagogical Centre].

Rovňanová, L. (2014b). Výchova k manželstvu a rodičovstvu a etike intímnych vztahov: základné východiská. [Education For Marriage and Parenthood and Ethics of Intimate Relationsgips: elementary foundations]. Bratislava: Metodicko-pedagogické centrum [Methodological and Pedagogical Centre].

Schmidt, G. (2003). Zur Sozialgeschichte der Jugendsexualität in der zweiten Hälfte 20. Jahrhunderts. In AIDS INFOTHEK: Das Magazin der Aids Info Docu Schweiz, 15, 4-9.

Stich, J. (2003). Annäherungen an Sexualität: Ein empirisches Forschungsprojekt mit Jugendlichen. Zeitschrift für Sexualforschung, 16(02), 99-115.

Supeková, M., \& Bianchi, G. (2000). Sexuálna výchova a spokojnost' sexuálne aktívnejších mladých lúdí (kvalitatívny prístup). [Sex Education and Contentment of the Sexually Active Youth (qualitative approach)]. Československá psychologie [Czechoslovak Psychology], 1, 56-76.

Szabó, I., \& Švihelová, D. (2001). Skúsenosti mladých lúuí v oblasti sexuality. [Experience of Youth in the Field of Sexuality]. In 9. celostátní kongres k sexuální výchově v České republice. Pardubice 2001. Sborník referátü. [9th National Congress on Sex Education in the Czech Republic. Pardubice 2001. Conference Proceedings] (pp. 129-135). Prague: Společnost pro plánování rodiny a sexuální výchovu v Praze a Nová tiskárna Pelhřimov [Society for Family Planning and Sex Education in Prague and New Printing House Pelhřimov]. 


\section{Author}

prof. PhDr. Dagmar Marková, PhD.

Faculty of Arts, Constantine the Philosopher University in Nitra

Department of General and Applied Ethics

Hodžova 1, 94974 Nitra, The Slovak Republic

dmarkova@ukf.sk 